Article citation info:

AMBROSEWICZ-WALACIK, M., TAŃSKA, M., WALACIK, M., NITKIEWICZ, S. Production of fuel blends from diesel oil and waste products. Combustion Engines. 2017, 171(4), 255-258. DOI: 10.19206/CE-2017-443

Marta AMBROSEWICZ-WALACIK

CE-2017-443

Małgorzata TAŃSKA

Marek WALACIK

Szymon NITKIEWICZ

\title{
Production of fuel blends from diesel oil and waste products
}

The aim of the study was to evaluate the physico-chemical parameters of the fuel blends consist of a diesel oil and waste products, such as a pyrolytic oil from car tires and a frying oil. The samples were characterized by the kinematic viscosity at $40^{\circ} \mathrm{C}$, density at $15^{\circ} \mathrm{C}$, acid value, sulphur content, temperature of flash point and temperature of cold filter plugging point. The obtained results indicated that the fraction of the pyrolysis oil due to the very low temperature of flash-point and high sulphur content is a difficult material to use in the biofuels sector. While the sulphur content of that material may be reduced by the desulphurisation, whereas the increasing temperature of flash point, which greatly influenced the low value of this parameter for the mixture, is problematic. What is more, a high degree of oxidation of the frying oil determined too low stability of the produced methyl esters, and thus the fuel blends.

Key words: fuel blends, diesel oil, pyrolytic oil, frying oil, transestrification, physico-chemical properties

\section{Introduction}

The main hydrocarbon deposits (petroleum, natural gas) in Poland are located in Podkarpacie, Wielkopolska, in Lubuskie region and in Pomorze [1]. One of the main leaders of the exploration and production of petroleum on land is the Polskie Górnictwo Naftowe i Gazownictwo (PGNiG). The mining oscillates at the level of 1.2 million tons of the petroleum per year, which covers only a few percent of the annual demand. In turn, the main leader in the production of petroleum in the Baltic Sea leads the Lotus Group, which has in its possession two deposits of production, allowing to mined 7000 barrels of the crude oil per day. Mateusz Cabak, an employee of the Lotos company, reported that the Polish sea hidden beneath about 30 million tons of the crude oil, and therefore the search for this product are continued. According to "The balance of mineral deposits in Poland as of 31.12.2015" prepared by the Polish Geological Institute - Polish Research Institute, it was stated that the amount of mined resources in Poland is 139.84 billion cubic meters for natural gas; 23.22 million tons for crude petroleum; 27.04 billion tons for lignite and 59.79 bilions tons for coal. It was estimated that crude oil production covers only 3.5 percent of the national demand, while production of natural gas $1 / 3$. Only the mining of lignite and coal covers the annual Polish demand. However, as it is well known the conventional energy resources are non-renewable, and their resources will be depleted [2]. In the same time, the share of renewables will increase almost twice in comparison to 2010, and it will be equal to those of the nuclear power and petroleum. As GUS report presented, in 2014 the usage of electricity on 1 inhabitant was the highest in the Silesian Voivodeship (5 $579.9 \mathrm{kWh}$ ), and the lowest in Podlaskie (2 $367.61 \mathrm{kWh}$ ) [3]. The equivalent use of raw materials such as a rapeseed, soybean or sunflower for consumption and fuel purposes and a lack of the satisfactory programs to support the production of biofuels affect the doubtful profitability of the production. However, the quantitative targets " 3 x 20\%" established for 2020 by the European Union, which impose, among others, the increase of the use of the renewable energy sources to $20 \%$ of the total energy consumption in the EU, including their use in transport to $10 \%$, oblige the members to continuously increase the share of bio- components in conventional fuels. Among the main objectives of the energy policy concerning the use of renewable energy sources are: an increase the share of renewable energy sources in the final energy consumption to at least $15 \%$ in 2020 and further growth in the coming years; a gradually increase of biofuels share in the transport fuel market up to $10 \%$ in 2020 and a reduction of usage of first generation biofuels; an increase the degree of diversification of supply sources and the creation of appropriate conditions for the development of locally available raw materials. In terms of the use of biomass the attention is primarily turned to the use of more efficient energy solutions, for example, an usage of different methods of gassing and processing into liquid fuels, with particular focus on the second generation biofuels. Currently, the increased interest in the use of waste materials can also be observed. Due to the economic and ecological reasons, it seems to be reasonable to use residual fats and oils. However, the application of these raw materials is associated with prior processes of oil purification, which are sometimes complex and expensive [4]. However, despite the low price encouraging their use, they are a "difficult" raw material for the biodiesel production. Namely, waste vegetable and animal fats are characterised by the increased content of free fatty acids, water, solid contaminants, phosphorus compounds and polymers, which impede and sometimes prevent the transesterification process [5]. Moreover, the main problem of the use of these materials is related to a lack of an appropriate legislation to support their collection from catering establishments, which amount, in 2014, was estimated at 65 509, including 16473 restaurants, 23634 bars, canteens 4014 and eateries 21761 [3,6]. From an ecological point of view, use of the other waste materials, or plastic solid waste (PSW) and waste tyres also seems an important issue [7]. The last group includes pyrolysis, which is defined as controlled burning or heating (400$700^{\circ} \mathrm{C}$ ) of a material in the absence of oxygen. Organic components of a raw material are decomposed, generating liquid and gaseous products that can be used as fuels, while 
inorganic ingredients remain practically unaltered and free of binding organic matter [8,9]. A similar composition of pyrolytic oil and petroleum indicates the possibility of application of these materials in the production of alternative fuels; therefore, technologies for processing waste tyres are constantly being improved [10]. In 2016 in Poland, 47 of the of waste incinerators were reported. These places may contribute to the recovery of the valuable products, including fuel. Due to the above the aim of presented work was to determine the possibility of use a ternary mixture as a power source for diesel engines.

\section{Material and analitical methods}

The research materials were 3 different samples: a diesel fuel purchased on the commercial fuel stations in 2016, in Olsztyn; a pyrolysis oil sample, that was collected from a private investor and a waste oil obtained from regional point of catering. In the first stage of an experimental part the pyrolytic oil and waste frying oil had to be properly prepared for later use. In the case of the pyrolytic oil the distillation process was used to obtain a medium fraction of naphta, which served as one of a component of fuel mixture. Firstly, the sample was heated to $160^{\circ} \mathrm{C}$ whereby the light fraction of naphta was separated $(2 \%)$. Then the temperature was gradually increased to approx. $204^{\circ} \mathrm{C}$, what allowed to isolate approx. $49 \%$ of medium fraction. In turn, the frying oil was analysed in terms of the hydrolysis degree (acid value by PNEN14104:2004P, \%FFA share of free fatty acids), oxidation degree (peroxide value according to PN-EN ISO 3960:2012P) and fatty acid composition (PN-EN ISO 12966-4:2015-07E') (Table 1). The results of the analysis led to the conclusion that the appropriate transesterification method will be the acid-base reaction. The above decision was related to the high acid value $(7.24 \mathrm{mg} \mathrm{KOH} / \mathrm{g})$.

Table 1. Characterization of the frying oil

\begin{tabular}{|l|c|}
\hline Distriminats & Frying oil \\
\hline Acid value $(\mathrm{mg} \mathrm{KOH} / \mathrm{g})$ & 7.24 \\
\hline \% FFA & 3.62 \\
\hline Peroxide value $\left(\mathrm{mEq} \mathrm{O}_{2} / \mathrm{kg}\right.$ oil) & 12.07 \\
\hline Composition of fatty acids (\%) & \\
- myristic $\mathrm{C}_{14: 0}$ & 0.15 \\
- palmitic $\mathrm{C}_{16: 0}$ & 7.57 \\
- palmitoleic $\mathrm{C}_{16: 1}$ & 0.21 \\
- stearic $\mathrm{C}_{18: 0}$ & 3.26 \\
- oleic $\mathrm{C}_{18: 1}$ & 76.86 \\
- linoleic $\mathrm{C}_{18: 2}$ & 7.78 \\
- linolenic $\mathrm{C}_{18: 3}$ & 0.48 \\
- arachidic $\mathrm{C}_{20: 0}$ & 0.88 \\
- eicosenoic $\mathrm{C}_{20: 1}$ & 1.88 \\
- behenic $\mathrm{C}_{22: 0}$ & 0.27 \\
& 0.86 \\
\hline
\end{tabular}

\section{Description of the transestrification proces}

In the first stage of the transestrification to $200 \mathrm{~g}$ of a heated oil (up to $60^{\circ} \mathrm{C}$ ) $224 \mathrm{ml}$ of a methanol and $2 \%$ of $\mathrm{H}_{2} \mathrm{SO}_{4}$ (v/v) were added. The reaction was at $60^{\circ} \mathrm{C}$ during 1.5 $\mathrm{h}$. After the reaction the mixture was subjected to the sedimentation for $24 \mathrm{~h}$, in order to obtained the upper ester phase. Then the separated phase was poured into glass flasks and the second stage of transesterification was carried out $-0.5 \%$ of a potassium hydroxide was dissolved in $27.0 \mathrm{ml}$ of a methanol and then added to ester phase. The reaction was carried out at $60^{\circ} \mathrm{C}$ for $0.5 \mathrm{~h}$. The ester phase after the second stage of the reaction was isolated as described above. The yield of the ester production was determined with using the thin liquid chromatography (TLC) technique (85.29\%) (Fig. 1).

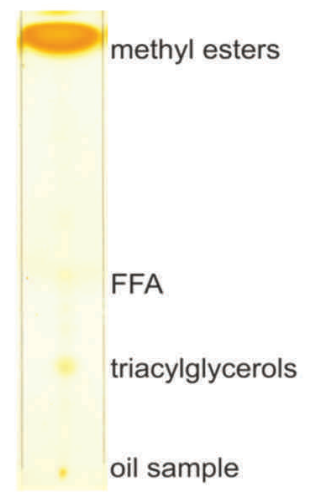

Fig. 1. TLC chromatogram of esters obtained by the double base-acid transesterification

After preparing the components of the mixture, each of them has been analysed in terms of a kinematic viscosity at $40^{\circ} \mathrm{C}$ (ISO 3104), density at $15^{\circ} \mathrm{C}$ (ISO 12185), temperature of flash point (PN-EN ISO 3679), temperature of cold filter plugging point (EN 116), sulphur content (EN ISO 20884) and oxidation stability (ISO 14112) (Table 2).

Table 2. Characteristics of the prepared raw materials

\begin{tabular}{|l|c|c|c|}
\hline Discriminants & $\begin{array}{c}\text { Fraction of } \\
\text { pyrolytic } \\
\text { oil }\end{array}$ & $\begin{array}{c}\text { Esters of } \\
\text { frying oil }\end{array}$ & $\begin{array}{c}\text { Diesel } \\
\text { oil }\end{array}$ \\
\hline Viscosity at $40^{\circ} \mathrm{C}\left(\mathrm{mm}^{2} / \mathrm{s}\right)$ & 1.05 & 3.63 & 3.05 \\
\hline Density at $15^{\circ} \mathrm{C}\left(\mathrm{kg} / \mathrm{m}^{3}\right)$ & 870 & 878 & 835 \\
\hline Flash point $\left({ }^{\circ} \mathrm{C}\right)$ & 12 & 194 & 56 \\
\hline Cold filter plugging point $\left({ }^{\circ} \mathrm{C}\right)$ & $<-30$ & -1 & -18 \\
\hline Acid value $(\mathrm{mg} \mathrm{KOH} / \mathrm{g})$ & 3.56 & 0.04 & 0.049 \\
\hline Sulphur content $(\%)$ & 1.22 & 0.004 & 0.005 \\
\hline Oxidative stability $(\mathrm{h})$ & $>20$ & 1.44 & 20.63 \\
\hline
\end{tabular}

Analysing the results of the study it was found that in case of the methyl esters derived from the frying oil, most quality parameters met the requirements of PN EN 14214+A1:2014-04. An exception was only the oxidation stability, which the minimum limit has been increased from 6 to $8 \mathrm{~h}$. What is more, taking into account the yield of the methyl esters production it was found that $85.29 \%$ is not enough satisfying result. The sample of the diesel oil did not show any irregularities. One the other hand, most of the determined parameters for the medium fraction of naphta did not meet requirements of the quality standards for the diesel fuel and methyl esters. Noteworthy were especially too low the temperature of flash point, that determine the safety use of the fuel samples, as well as an increased the free fatty acids content and sulphur content. The presented results indicating, that the analysed medium fraction of naphta should not be used as an individual fuel, however it is believed that it can be use as one of the minor components of the fuel mixtures. 
Production of fuel blends from diesel oil and waste products

After conducting the physico-chemical characteristics of the prepared components 4 fuel mixtures were prepared, in proportions presented in Table 3 .

Table 3. Composition of the fuel blends ( $\% \mathrm{v} / \mathrm{v})$

\begin{tabular}{|c|c|c|c|}
\hline $\begin{array}{c}\text { Fuels } \\
\text { blends }\end{array}$ & $\begin{array}{c}\text { Fraction of } \\
\text { pyrolytic oil }\end{array}$ & $\begin{array}{c}\text { Esters of frying } \\
\text { oil }\end{array}$ & Diesel oil \\
\hline $\mathrm{FB}_{1}$ & 1.0 & 49.5 & 49.5 \\
\hline $\mathrm{FB}_{2}$ & 1.0 & 69.0 & 39.0 \\
\hline $\mathrm{FB}_{3}$ & 2.0 & 49.0 & 49.0 \\
\hline $\mathrm{FB}_{4}$ & 2.0 & 60.0 & 39.0 \\
\hline
\end{tabular}

\section{Results and discusion}

It was found that almost all of the analysed physicochemical parameters for the fuel blends, except for the viscosity, density, temperature of cold filter plugging, did not meet requirements of the European Union standards.

Duo to too low value of the temperature of flash point, it would not be possible to direct these samples for the general use. Despite the high share of the frying oil methyl esters (flash point $-190^{\circ} \mathrm{C}$ ) and diesel oil (flash point $-56^{\circ} \mathrm{C}$ ), the addition of even a small amount of pyrolytic fraction significant decreased the value of that parameter (Table 4). It is believed that it was related to the volatile compounds of the medium fraction of the pyrolytic car oil.

The value of the cold filter plugging point can be considered as acceptable (the lowest one $-5^{\circ} \mathrm{C}$ for $\mathrm{FB}_{3}$ sample and the highest one $-2^{\circ} \mathrm{C}$ for both $\mathrm{FB}_{1}$ and $\mathrm{FB}_{2}$ samples), when spring and summer periods are concerned. It is believed that high share of saturated acid in frying oil has important effect of high temperature of that parameter. Muniyappa et al. (1996), found that that methyl esters from a beef tallow oil were characterized by the high cold point, what was involved with high concentration of saturated fatty acid methyl esters [11]. Mittelbach and Remschmidt (2004), Wang et al. (2012) and Chuah et al. (2016) explained that during biodiesel cooling, the first fraction to precipitate is the stearic and palmitic methyl esters [12-14]. What is more, these components constitute a substantial share of the material that are recovered from the clogged biodiesel fuel filters.

The next unacceptable parameter of the analysed fuel blends was sulphur content. As PN EN 14214+A1:201404 and PN-EN 590: 2013-12 standards determine the highest acceptable sulphur content is $10 \mathrm{ppm}$. The analysed fuel blends were characterized by the 6 -fold $\left(\mathrm{FB}_{1}\right.$ and $\mathrm{FB}_{2}$ samples) and 12-fold ( $\mathrm{FB}_{3}$ and $\mathrm{FB}_{4}$ samples) higher content of that compound (Table 4). Bocheński and Bocheńska (2005) reported that the sulphur contained in the fuel products has a significant impact on its corrosive action, but also on the lubricity of the fuel and the formation of sulphur oxides [15]. Olesiak and Stępień (2008) found that the reduced amount of sulphur and aromatic hydrocarbons in fuels has a positive effect from the ecological point of view, however these compounds are characterized by the good anti-wear properties, and their removal has significant effect on the deterioration of lubricity of fuel, what is also results in the deterioration of the engine work [16].
Table 4. Characteristics of the prepared fuel blends

\begin{tabular}{|l|c|c|c|c|}
\hline \multirow{2}{*}{ Discriminants } & \multicolumn{4}{|c|}{ Fuels blends } \\
\cline { 2 - 5 } & $\mathrm{FB}_{1}$ & $\mathrm{FB}_{2}$ & $\mathrm{FB}_{3}$ & $\mathrm{FB}_{4}$ \\
\hline Viscosity at $40{ }^{\circ} \mathrm{C}\left(\mathrm{mm}^{2} / \mathrm{s}\right)$ & 3.30 & 3.38 & 2.93 & 3.21 \\
\hline Density at $15^{\circ} \mathrm{C}\left(\mathrm{kg} / \mathrm{m}^{3}\right)$ & 853 & 848 & 849 & 852 \\
\hline Flash point $\left({ }^{\circ} \mathrm{C}\right)$ & 37 & 36 & 31 & 29 \\
\hline Cold filter plugging point $\left({ }^{\circ} \mathrm{C}\right)$ & -2 & -2 & -5 & -4 \\
\hline Sulphur content $(\mathrm{ppm})$ & 61.0 & 63.1 & 122.9 & 121.9 \\
\hline Oxidative stability $(\mathrm{h})$ & 3.23 & 1.73 & 3.43 & 2.23 \\
\hline
\end{tabular}

The oxidative stability of the fuel blends was determined by a low stability of the frying oil methyl esters (1.44 $\mathrm{h}$, Table 2). The value of that parameter ranged from $1.73 \mathrm{~h}$ for $\mathrm{FB}_{2}$ sample to $3.43 \mathrm{~h}$ for $\mathrm{FB}_{3}$ sample (Table 4). The higher share of the frying oil esters, the lower resistance to oxidation (Table 3,4 ). The degradation of the diesel fuels is generally due to the oxidation. The main signs of the oxidative stability decrease are an increased acid value and viscosity, as well as the formation of gums and sediments. The first stage of the oxidation process is associated with the hydroperoxides formation. That reaction is caused by the addition of an oxygen molecule to a carbon atom adjacent to a $\mathrm{C}=\mathrm{C}$ double bond. During the oxidation process the peroxides break away to form aldehydes and short-chain acids. Free radicals can be also generated by peroxides. These newly formed compounds promote the polymerization and crosslinking among the olefinic molecules [17]. As the cited authors found the oxidation reactivity is in an inverse correlation with the degree of $\mathrm{C}=\mathrm{C}$ bonds in the fuel. Jakóbiec and Ambrozik (2008) found that the main external factors influenced the oxidative stability of motor fuels, including the vegetable oil methyl esters, are an increasing temperature, presence of air, light, oxygen and metals that catalyse the oxidation process. In turn, the internal factors determining the susceptibility to oxidation are related to the chemical composition and quality of raw material, as well as the conditions of the transesterification [18].

\section{Conclusions}

The prepared fuel blends met 3 from 6 of the requirements for analysed parameters. Among them the viscosity, density and temperature of cold filter plugging point should be listed. It is worth to mention, that even $1 \%$ addition of the medium fraction of naphta, distilled from the pyrolytic car oil, characterized by a very low temperature of flash point caused the significant decrease of that parameter values for the fuel blends. What is more, stated in the presented work a high sulphur content in the naphta sample had an influence on the increased amount of that compound in the composed blends, significantly exceeding permissible level (10 ppm). Therefore, it is believed the desulfurization process of the pyrolytic oil would be needed to reduce increased sulphur content. On the other hand, noticed for the frying oil methyl esters a low oxidative stability determined an unacceptable value of that parameter for analysed ternary samples. For that reason, it is found that the produced methyl esters of the frying oil were not a suitable raw material for the biofuels production, because of the high share of easily oxidising fatty acids and high value of the peroxide value. 


\section{Bibliography}

[1] CEBULA, P. Samowysarczalność energetyczna Polski. Nowy Dziennik - Polish Daily News. www.dziennik.com/ publicystyka/artykul/samowystarczalnosc-energetyczna-polski (publ. 25.08. 2016) (accessed 10.01.2017).

[2] BARTOSIK, M., KAMRAT, W., KAŹMIERKOWSKI, M. et al. Bezpieczeństwo elektroenergetyczne pokoleń. Przeglad Elektrotechniczny. 2016, 92(8), 268-282.

[3] GUS 2015. Główny Urząd Statystyczny 2015. Maty rocznik statystyczny Polski. 2015, 175.

[4] KARMAKAR, A., KARMAKAR, S., MUKHERJEE, S. Properties of various plants and animals feedstocks for biodiesel production. Bioresour. Technol. 2010, 101(19), 201-210.

[5] TAŃSKA, M., ROTKIEWICZ, D., BĄC $\square \mathrm{EK}, \quad \mathrm{N}$. Adsorpcyjne oczyszczanie tłuszczów posmaż $\square$ zy przeznaczonych do produkcji biodiesla. Przyroda Nauka Technologie. 2012, 6, 1-11.

[6] KUPCZYK, A., MANTEUFFEL, W., RUCIŃSKI, D., WIŚ $\square$ IEWSKI, G. Analiza rynku paliw płynnych pochodzenia roślinnego do celów energetycznych. 2008, IEO na zlecenie EC Rzeszów.

[7] LUO, G., SUTO, T., YASU, S., KATO, K. Catalytic degradation of high density polyethylene and polypropylene into liquid fuel in a powder-particle fluidized bed. Polymer Degradation and Stability. 2007, 70(1), 97-102.

[8] PANDA, A.K., SINGH, R.K., MISHRA, D.K. Renewable and Sustainable Energy Review.

[9] ADRADOS, A., DE MARCO, I., CABAllero, A. et al. Pyrolysis of plastic packaging waste: a comparison of plastic residuals from material recovery facilities with simulated plastic waste. Waste Manage. 2012, 32(5), 826-832.

[10] SUROVKA, D., PERTILE, E., LORENZ, T. et al. Potencjalny odzysk energii $\mathrm{z}$ produktów pirolitycznej obróbki odpadów. I żynieria Mineralna. 2012, 13(2), 43-48.

[11] MUNIYAPPA, P.R., BRAMMER, S.C., NOUREDDINI, H. Improved conversion of plant oils and animal fats into biodiesel and co-product. Bioresour. Technol. 1996, 56(1), 19-24.

[12] MITTELBACH, M., REMSCHMIDT, C. Biodiesel: The Comprehensive Handbook Boersedruck GmbH. 2004, Vienna, Austria.

[13] WANG, L.B., YU, H.Y., HE, X.H., LIU, R.Y. Influence of fatty acid composition of woody biodiesel plants on the fuel properties. J. Fuel Chem. Technol. 2012, 40(4), 397-404.

[14] CHUAH, L.F., YUSUP, S. AZIZ, A.R.A. et al. Influence of fatty acid content in non-edible oil for biodiesel properties. Clean Technol. Environ. Policy. 2016, 18(2), 473-482.

[15] BOCHEŃSKI, C.J., BOCHEŃSKA, A. Badania mieszaniny oleju napędowego $\mathrm{z}$ estrami metylowymi oleju rzepakowego. MOTROL. 2005, 7, 24-34.

[16] OLESIAK, S., STĘPIEŃ, Z. Zagadnienia smarności ciekłych paliw silnikowych. Czasopismo Techniczne Mechanika. 2008, 105(7), 251-263.

[17] TANG, H., SALlEY, S.O., NG, K.Y.S. Michigan Ohio University Transportation Center Subtitle: Improved oxidative stability of biodiesel fuels: antioxidant research and development. Report No: MIOH UTC AF4p2-5 2011Final MDOT Report No: RC1545, 2011, 1-46.

[18] JAKÓBIEC, J., AMBROZIK, A. Wybrane właściwości fizykochemiczne i użytkowe estrów metylowych kwasów tłuszczowych oleju rzepakowego jako paliwa silnikowego. Inżynieria Rolnicza. 2008, 9(107), 107-115.

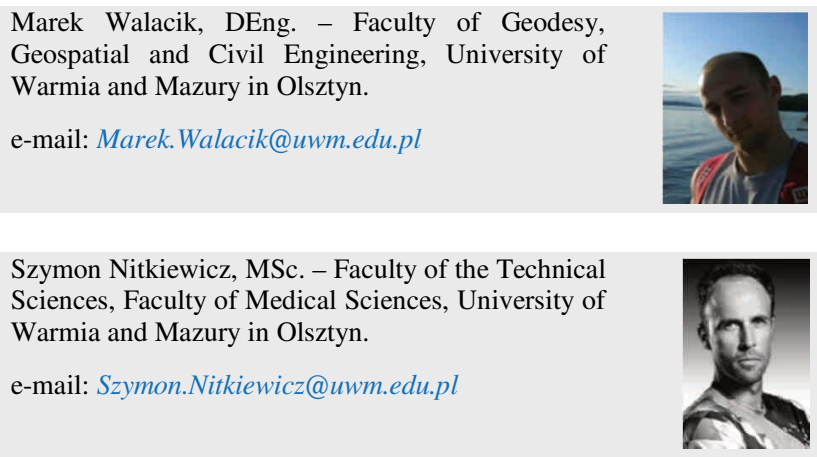

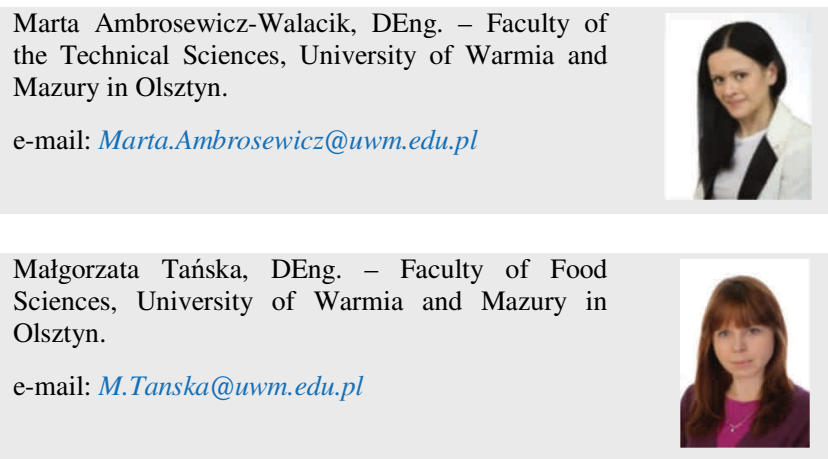

Marta Ambrosewicz-Walacik, DEng. - Faculty of the Technical Sciences, University of Warmia and Mazury in Olsztyn.

e-mail: Marta.Ambrosewicz@uwm.edu.pl

Małgorzata Tańska, DEng. - Faculty of Food Sciences, University of Warmia and Mazury in Olsztyn. 